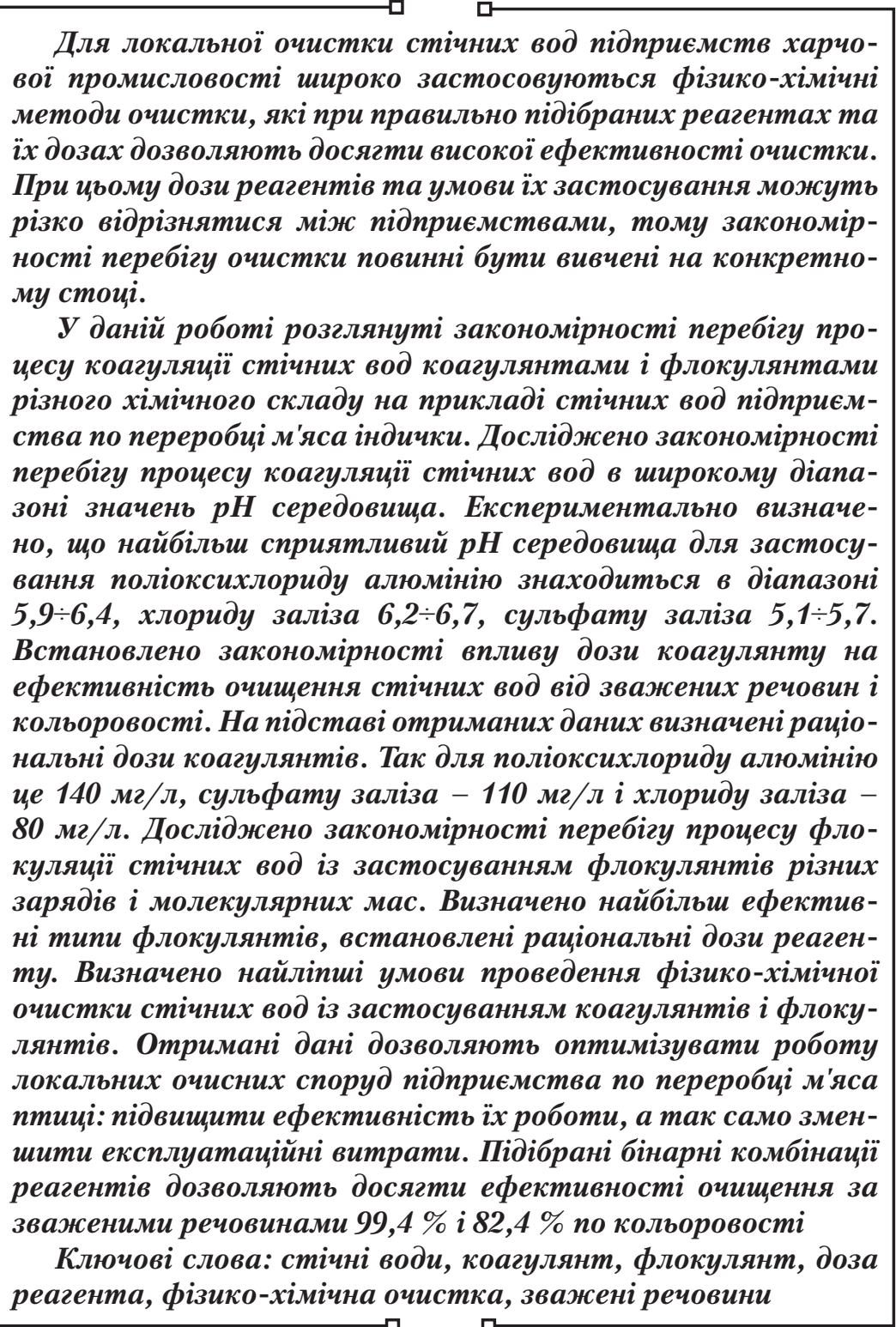

UDC 628.345.4

DOI: $10.15587 / 1729-4061.2018 .131122$

\section{A STUDY OF WASTEWATER TREATMENT CONDITIONS FOR THE POULTRY MEAT PROCESSING ENTERPRISE}

\author{
K. Makhlay \\ Postgraduate student* \\ E-mail: cancermakh@gmail.com
}

M. Tseitlin

Doctor of Technical Sciences, Professor* E-mail: michelzeitlin@gmail.com V. Raiko

PhD, Professor*

E-mail: raiko.hpi@gmail.com

*Department of chemical technique and industrial ecology

National Technical University «Kharkiv Polytechnic Institute»

Kyrpychova str., 2, Kharkiv, Ukraine, 61002

\section{Introduction}

The food industry is one of the most developed and largest sectors of the national economy of Ukraine, which not only provides the domestic market, but is also a major exporter of products. One of its largest branches is processing of meat products, where poultry meat production prevails, about $49 \%$, which is more than 700 thousand tons of finished products per year [1]. In the production of meat products, from 6 to $30 \mathrm{~m}^{3}$ of pure water per ton of finished products is used [2]. At the current production level, it is more than 2 million $\mathrm{m}^{3}$ of wastewater a year.

At the same time, most enterprises have low-efficiency treatment facilities or do not have them at all. This situation leads to the fact that untreated or poorly treated wastewater is discharged into a municipal sewage system or a nearby water body, thus worsening the ecological condition of water basins [3].

A total of $92 \%$ of fresh water used by mankind, in one way or another, accounts for the food industry, more than a third of which is spent for production of meat products $[4,5]$.

\section{Literature review and problem statement}

Wastewater from the enterprises for the production of meat products represents complex high-concentrated systems $[6,7]$. The main types of pollutants are blood, wool, mineral inclusions, paunch manure, skin, feather $[8,9]$.

For the local treatment of wastewater of food industry enterprises, pressure flotation units with preliminary physicochemical processing are the most widely used [10]. As reagents, coagulants based on aluminum and iron salts are most often applied [11], which, when properly dosed, give a high treatment efficiency [12]. At the same time, the review of recent studies shows that it is very difficult to determine the doses based on the available results due to a considerable variation of the data obtained. So, in [13], using iron chloride for removal of dyes from wastewater, it has been found that the optimum $\mathrm{pH}$ range of the medium is $3 \div 4$ and the coagulant dose is $40 \mathrm{mg} / \mathrm{l}$.

When using the same coagulant for dairy's wastewater, it turned out that at almost the same $\mathrm{pH}$ value, namely 4.5, the coagulant dose of $200 \mathrm{mg} / \mathrm{l}$ was required [10]. That is 
5 times more. For slaughterhouse wastewater, according to [14], the working range of $\mathrm{pH}$ was within $5.83 \div 6.28$ (significantly higher than in [13]), and the coagulant dose reached $600 \mathrm{mg} / \mathrm{l}$.

A similar variation of results occurs in studies on the use of iron sulfate as a coagulant for the dairy's wastewater treatment. Thus, in [10], it has been found that the optimum $\mathrm{pH}$ is 7.6 , and the coagulant dose is $200 \mathrm{mg} / \mathrm{l}$. Other studies have found that $\mathrm{pH}=5$ is optimum for the treatment of the same wastewater, and the coagulant dose reaches $1,000 \mathrm{mg} / \mathrm{l}$ [15]. As for wastewater of the pig meat processing plant, as found in [16], the coagulation workflow proceeds most intensively at $\mathrm{pH}=10$ and the coagulant dose of $350 \mathrm{mg} / \mathrm{l}$.

This variation of data is associated with many factors, beginning with the reagents and production standards used, ending with the quality of tap water at the enterprise [17, 18].

From the above, it becomes obvious that the optimum conditions for the application of coagulants for each particular enterprise are highly individual and are subject to study and testing at a particular drain.

\section{The aim and objectives of the study}

The aim of the study was to increase the efficiency of local sewage treatment facilities by rationalizing the operating conditions of physicochemical wastewater treatment facilities. In particular, by experimental substantiation of rational doses of reagents and conditions of their application.

To achieve the aim of the study, the working ranges of $\mathrm{pH}$ of the medium for each of the studied types of coagulants were determined first, coagulation thresholds were identified, and rational doses of reagents were established. At the second stage of the study, the regularities of the action of flocculants with different charge and molecular weight were studied and the most preferable combinations thereof were determined.

\section{Materials and methods of the study of chemical wastewater treatment efficiency when using coagulants and flocculants}

The subject of the study was wastewater of the slaughterhouse of the turkey meat processing enterprise. The major amount of wastewater of the enterprise results from slaughter and evisceration of poultry, preparation of natural chopped semi-finished products, washing and disinfection of equipment and premises.

Industrial wastewater contains fats, proteins, organic particles, as well as mechanical impurities and sand. To ensure trouble-free operation of the general sewage system at the slaughterhouse outlet, before wastewater discharge into the general sewage system, local treatment facilities - grease trap and sand trap are installed.

The characteristics of the wastewater subject to treatment are given in Table 1.

The following reagents were used in the study:

1. Coagulants: AQUA-AURAT-18 polyaluminum chloride TU 2163-069-00205067-2007; $\left(\mathrm{Al}_{2} \mathrm{O}_{3}=17 \pm 0.5 \%\right)$ FER-AQUA-17 $\left(\mathrm{Fe}_{2}\left(\mathrm{SO}_{4}\right)_{3}\right.$ iron-containing coagulant TU U 20.1-03327724-006: 2013, the mass fraction of $\mathrm{Fe}^{3+}$ not less than $13.7 \%$ ); $\mathrm{FeCl}_{3}$ iron chloride coagulant TU 2152-081-56856807-08, the mass fraction of iron chloride not less than $40 \%$.
2. Flocculants: Flopam AN 934 SH polyacrylamide anionic flocculant with an average charge density, very high molecular weight, Flopam AN 926 SH polyacrylamide anionic flocculant with an average charge density, very high molecular weight; Flopam FO $4490 \mathrm{SH}$ and Flopam FO $4440 \mathrm{SH}$ polyacrylamide cationic flocculants with an average charge density and high molecular weight.

3. Reagents for $\mathrm{pH}$ adjustment: sodium hydroxide $\mathrm{NaOH}$ by GOST R 55064-2012; hydrochloric acid ( $\mathrm{HCl} 35-38 \%$ ) by GOST 3118-77.

Table1

Composition of industrial wastewater subject to treatment

\begin{tabular}{|c|c|c|}
\hline Parameter & Unit of measure & Value \\
\hline Suspended solids & $\mathrm{mg} / \mathrm{l}$ & $2,200 \div 4,000$ \\
\hline $\mathrm{COD}$ & $\mathrm{mgO}_{2} / \mathrm{l}$ & 6,000 \\
\hline $\mathrm{BOD}_{5}$ & $\mathrm{mgO}_{2} / \mathrm{l}$ & 2,500 \\
\hline Fats & $\mathrm{mg} / \mathrm{l}$ & 950 \\
\hline $\begin{array}{c}\text { Ammonium nitrogen } \\
\left(\mathrm{NH}_{4}-\mathrm{N}\right)\end{array}$ & $\mathrm{mg} / \mathrm{l}$ & 40 \\
\hline Phosphates & $\mathrm{mg} / \mathrm{l}$ & 70 \\
\hline $\mathrm{pH}$ & - & $6.5 \div 8.5$ \\
\hline $\begin{array}{c}\text { Maximum water } \\
\text { temperature }\end{array}$ & ${ }^{\circ} \mathrm{C}$ & 35 \\
\hline $\begin{array}{c}\text { Minimum water } \\
\text { temperature }\end{array}$ & ${ }^{\circ} \mathrm{C}$ & 24 \\
\hline
\end{tabular}

To determine the $\mathrm{pH}$, the wastewater collected from a neutralizer was poured into 0.5 -liter beakers. Then, a coagulant, a pH adjuster (acid or alkali) were added, and two-step mixing was performed: first fast and then slow. The resulting suspension was settled for 30 minutes, followed by sampling the treated water and measuring its quality.

Similarly, the coagulant dose was selected. In experiments on the selection of a rational dose in the binary coagulant - flocculant system, the coagulant dose found above was first added, the results of suspended solids removal and color reduction were estimated, then a flocculant was added and the result was estimated by the same wastewater treatment quality parameters.

The measurements were carried out using standard measuring instruments: portable waterproof $\mathrm{pH}$ Meter Hanna HI 9124 and HACH DR/890 colorimeter. Total suspended solids were measured in milligrams per liter and the color of the studied samples was determined in color degrees according to the Pt-Co scale by the photometric method.

The removal efficiency of suspended solids in percent was determined as the ratio of total suspended solids in the treated sample to those in the initial wastewater. The efficiency of color reduction in percent was determined as the ratio of the optical density of the treated sample to that of the initial wastewater.

The obtained experimental data were processed by means of spreadsheets on the MS Office Excel software.

\section{Results of studies of the regularities of the course of chemical wastewater treatment depending on the $\mathrm{pH}$ of the medium and reagent dose}

The results of determining the effective $\mathrm{pH}$ range for wastewater treatment using coagulants: polyaluminum chloride, iron sulfate and chloride are shown in Fig. 1, 2. The 
curves shown in the graphs below are not considered as an approximation of the experimental data and are given only to illustrate the possible nature of dependencies.

From the graph in Fig. 1, it can be seen that for all the coagulants studied, there is almost the same regularity in the effect of $\mathrm{pH}$ on the removal efficiency of suspended solids. At low $\mathrm{pH}$ values of $2 \div 4$, low treatment efficiency is observed, while with an increase in $\mathrm{pH}$ to $5.5 \div 6.5$, the suspended solids removal efficiency grows. The subsequent alkalization leads to a decrease in treatment efficiency. Similar regularities are also observed for the color reduction efficiency, as shown in Fig. 2.

The most acceptable $\mathrm{pH}$ range for the coagulation process when using the polyaluminum chloride coagulant is the range of values of $\mathrm{pH}-5.9 \div 6.4$; iron sulfate $-5.1 \div 5.6$; iron chloride $-6.2 \div 6.7$. Deviation from these ranges, both to lower and higher values, leads to a deterioration in treatment efficiency.

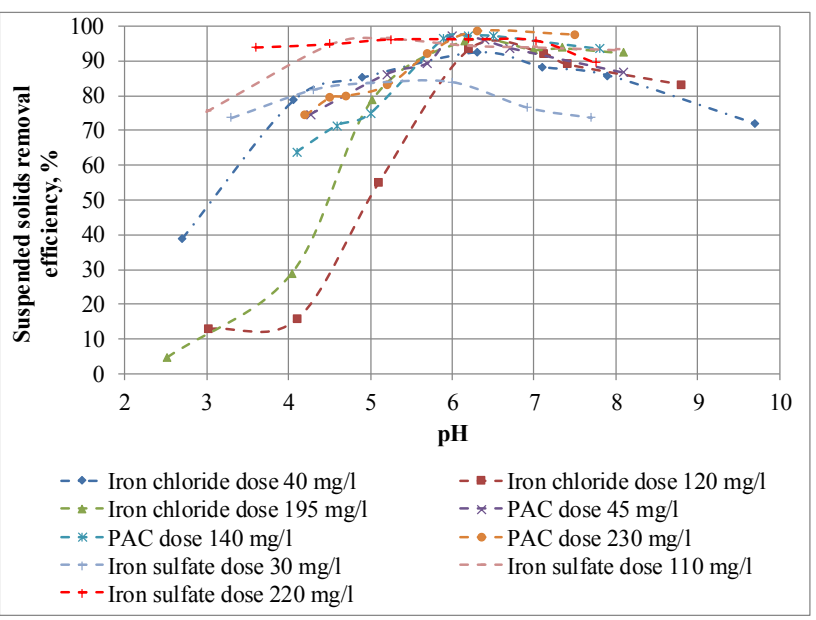

Fig. 1. Suspended solids removal efficiency when using polyaluminum chloride, iron sulfate and chloride coagulants with different doses and $\mathrm{pH}$

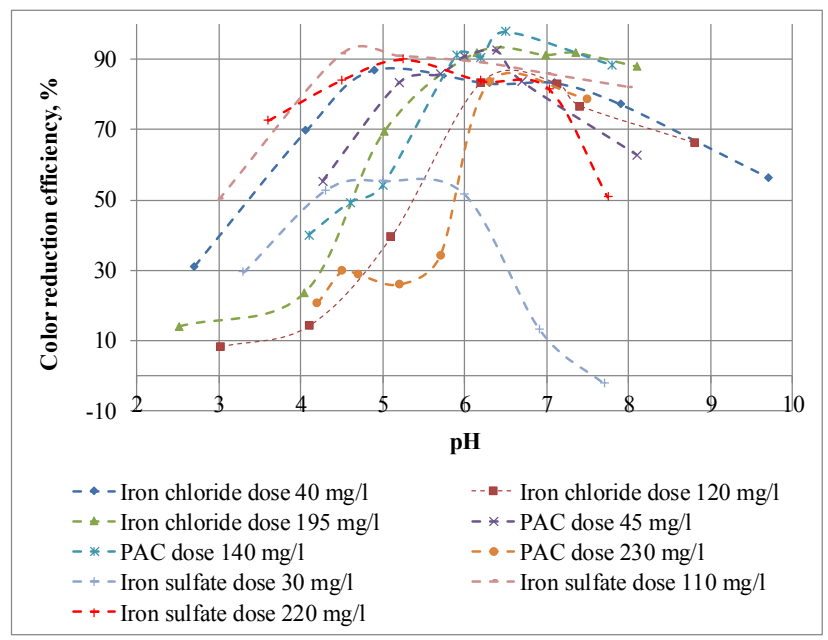

Fig. 2. Color reduction efficiency when using polyaluminum chloride, iron sulfate and chloride coagulants in the $\mathrm{pH}$ range of $2.5 \div 9.5$

The results of determining the rational coagulant dose are shown in Fig. 3. Polyaluminum chloride at a dose of $45 \mathrm{mg} / \mathrm{l}$ provides the suspended solids removal efficiency of $56.5 \%$. With the subsequent increase in the amount of reagent, the quality of treatment is improved, reaching the value of $91.8 \%$ at a dose of $185 \mathrm{mg} / \mathrm{l}$. The subsequent increase in the coagulant dose, up to $230 \mathrm{mg} / \mathrm{l}$, does not significantly improve the quality of treatment.

The dependence of wastewater treatment efficiency on the coagulant dose when using iron chloride is qualitatively similar. However, at a dose of $40 \mathrm{mg} / \mathrm{l}$, the suspended solids removal efficiency is much lower $-24.4 \%$. With the subsequent increase in the reagent dose, the quality of treatment is improved and reaches $72.9 \%$ at a dose of $80 \mathrm{mg} / \mathrm{l}$, but still remains lower than when using polyaluminum chloride. The subsequent increase in the coagulant dose to $195 \mathrm{mg} / \mathrm{l}$ does not significantly improve the quality of treatment.

Iron sulfate at a dose of $30 \mathrm{mg} / \mathrm{l}$ provides a $40.6 \%$ suspended solids removal efficiency. With the subsequent increase in the reagent dose to $110 \mathrm{mg} / \mathrm{l}$, treatment rate is increased to $73.7 \%$. Treatment efficiency is better than with the use of iron chloride, but worse than with polyaluminum chloride. The subsequent increase in the coagulant dose to $220 \mathrm{mg} / \mathrm{l}$, as with the use of other coagulants, leads only to minor improvements in the quality of treatment.

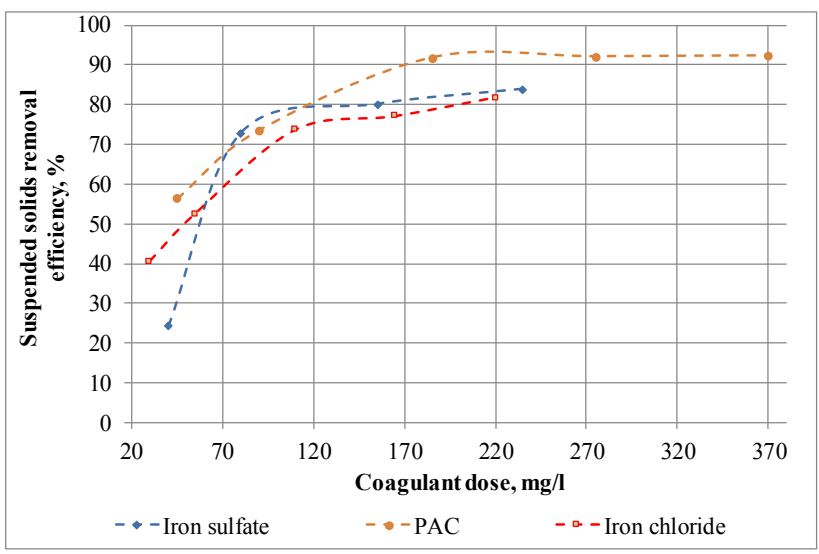

Fig. 3. Suspended solids removal efficiency when using polyaluminum chloride, iron sulfate and chloride coagulants with different doses at the optimum $\mathrm{pH}$

When using the binary coagulant - cathode flocculant system, an increase in the suspended solids removal efficiency for all types of flocculants and coagulants used is observed (Fig. 4).

The efficiency of combined use of polyaluminum chloride (a dose of $140 \mathrm{mg} / \mathrm{l}, \mathrm{pH}=5.9 \div 6.4$ ) and cationic flocculants (FO 4440 and FO 4490) is shown in Fig. 4. When adding the flocculant at a dose of $1.5 \mathrm{mg} / \mathrm{l}$, an increase in the suspended solids removal efficiency to 97.0 and $94.4 \%$, respectively, is observed. The subsequent increase in the flocculant dose to $3 ; 4.5 ; 6 \mathrm{mg} / \mathrm{l}$ does not significantly increase the efficiency.

The efficiency of combined use of iron sulfate (a dose of $110 \mathrm{mg} / \mathrm{l}, \mathrm{pH}=5.1 \div 5.7$ ) and cationic flocculants with different charge densities (FO 4440 and FO 4490) is similar (Fig. 4). At the flocculant dose of $1.5 \mathrm{mg} / \mathrm{l}$, the suspended solids removal efficiency is increased to $98.5 \%$ and $91.9 \%$, respectively. The subsequent increase in the flocculant dose to $6 \mathrm{mg} / \mathrm{l}$ does not significantly increase the removal efficiency of suspended solids.

The combined use of iron chloride (a dose of $80 \mathrm{mg} / \mathrm{l}, \mathrm{pH}=$ $=6.2 \div 6.7$ ) and cationic flocculants (FO 4440 and FO 4490) at a dose of $1.5 \mathrm{mg} / \mathrm{l}$ increases the suspended solids removal efficiency to 98.7 and $93.9 \%$, respectively. The subsequent 
increase in the flocculant dose to $6 \mathrm{mg} / \mathrm{l}$ does not improve the efficiency (Fig. 4).

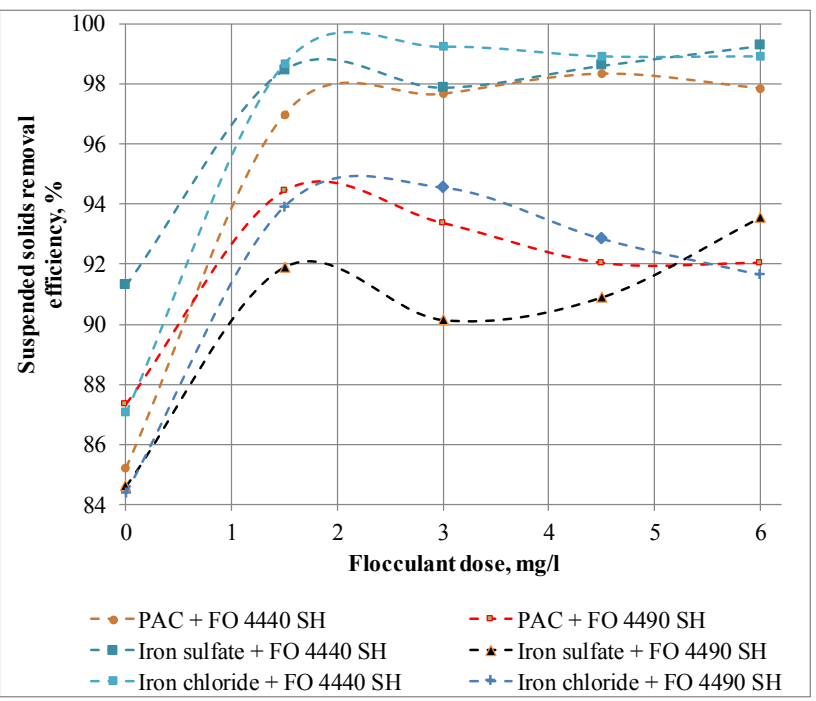

Fig. 4. Efficiency of suspended solids removal from wastewater when using the binary coagulant - cationic flocculant system

The results of color reduction when using the binary coagulant - cationic flocculant system are shown in Fig. 5.

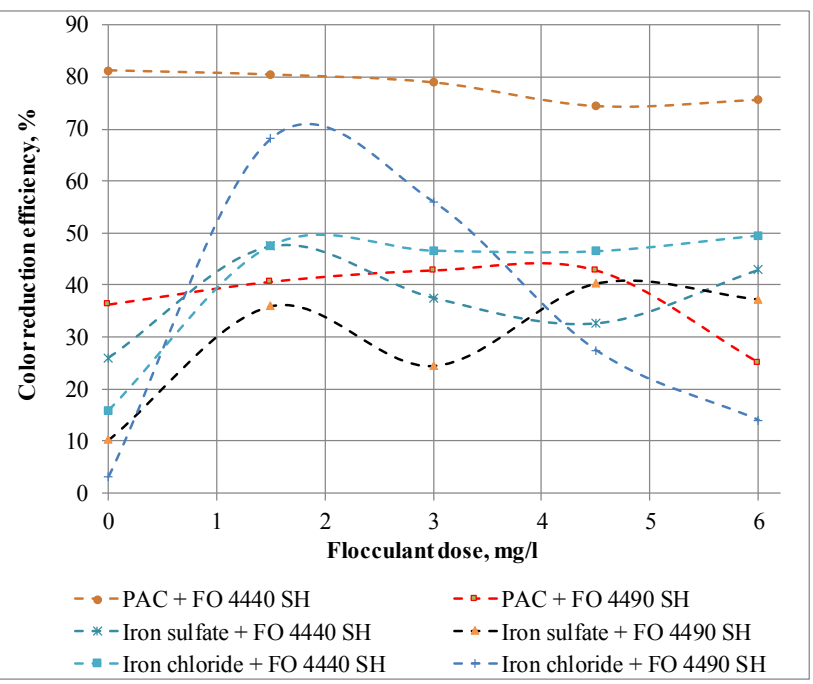

Fig. 5. Color reduction efficiency when using the binary coagulant - cationic flocculant system

For the iron sulfate coagulant, the color reduction efficiency when adding FO 4440 and FO 4490 cationic flocculants at a dose of $1.5 \mathrm{mg} / \mathrm{l}$ is increased to $47.5 \%$ and $39.5 \%$, respectively. The subsequent increase in the flocculant dose to $3 \mathrm{mg} / \mathrm{l}$ somewhat reduces efficiency to $37.5 \%$ and $24.5 \%$. With an increase in the flocculant dose to $4.5 \mathrm{mg} / \mathrm{l}$, the efficiency is increased again and accounts for $42.9 \%$ and $37.2 \%$, respectively.

For the binary system of iron chloride and FO 4440 cationic flocculant at a dose of $1.5 \mathrm{mg} / \mathrm{l}$, the efficiency is increased to $47.6 \%$ and with the subsequent increase in the dose to $4.5 \mathrm{mg} / \mathrm{l}$ remains practically unchanged. When using FO 4490 flocculant at a dose of $1.5 \mathrm{mg} / \mathrm{l}$, the dramatic increase in the color reduction efficiency to $68.1 \%$ occurs, the subsequent increase in the flocculant dose gradually reduces the effect and at a dose of $4.5 \mathrm{mg} / \mathrm{l}$ the efficiency is already $14 \%$.

For the polyaluminum chloride coagulant, the introduction of FO 4440 and FO 4490 cationic flocculants has little effect on the color reduction efficiency.

When using the binary coagulant - anionic flocculant system, an increase in the suspended solids removal efficiency for all types of flocculants and coagulants used is observed (Fig. 6).

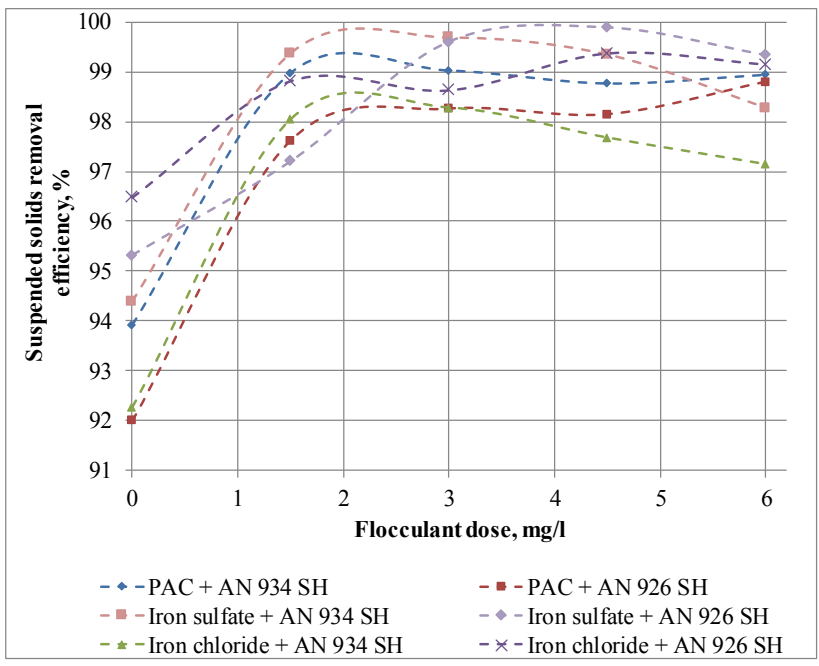

Fig. 6. Efficiency of suspended solids removal from wastewater when using the binary coagulant - anionic flocculant system

The efficiency of combined use of polyaluminum chloride (a dose of $140 \mathrm{mg} / \mathrm{l}, \mathrm{pH}=5.9 \div 6.4$ ) and anionic flocculants (AN $934 \mathrm{SH}$ and AN $926 \mathrm{SH}$ ) is shown in Fig. 6. When adding the flocculant at a dose of $1.5 \mathrm{mg} / \mathrm{l}$, the suspended solids removal efficiency is increased to 99.0 and $97.6 \%$, respectively. The subsequent increase in the flocculant dose up to $6 \mathrm{mg} / \mathrm{l}$ does not increase the efficiency, but also no significant changes in efficiency occur.

When using the binary system of iron sulfate (dose $110 \mathrm{mg} / \mathrm{l}, \mathrm{pH}=5.1 \div 5.7$ ) and anionic flocculant (AN $934 \mathrm{SH}$ and AN $926 \mathrm{SH}$ ) at a dose of $1.5 \mathrm{mg} / \mathrm{l}$, the suspended solids removal efficiency is increased to $99.4 \%$ and $97.2 \%$ respectively. The subsequent increase in the flocculant dose up to $6 \mathrm{mg} / \mathrm{l}$ does not affect the efficiency.

The combined use of iron chloride (a dose of $80 \mathrm{mg} / \mathrm{l}$, $\mathrm{pH}=6.2 \div 6.7$ ) and anionic flocculants (AN 934 SH and AN $926 \mathrm{SH}$ ) at a dose of $1.5 \mathrm{mg} / \mathrm{l}$ improves the suspended solids removal efficiency to 98.0 and $98.8 \%$ respectively. The subsequent increase in the flocculant dose does not significantly increase the efficiency.

When using the binary coagulant- anionic system, the results shown in Fig. 7 were obtained.

For the iron sulfate coagulant, the color reduction efficiency, when adding AN $926 \mathrm{SH}$ anionic flocculant at a dose of $1.5 \mathrm{mg} / \mathrm{l}$, is reduced to $43.8 \%$. The subsequent increase in the dose to $3 \mathrm{mg} / \mathrm{l}$ increases the efficiency to $83.8 \%$, and this efficiency remains with the subsequent dose increase up to $6 \mathrm{mg} / \mathrm{l}$. With the addition of AN 934 anionic flocculant at a dose of $1.5 \mathrm{mg} / \mathrm{l}$, the color reduction efficiency is increased to $82.5 \%$ and remains up to a dose of $4.5 \mathrm{mg} / \mathrm{l}$. With the subsequent increase in the flocculant dose to $6 \mathrm{mg} / \mathrm{l}$, the efficiency is reduced to $61.1 \%$ (Fig. 7). 


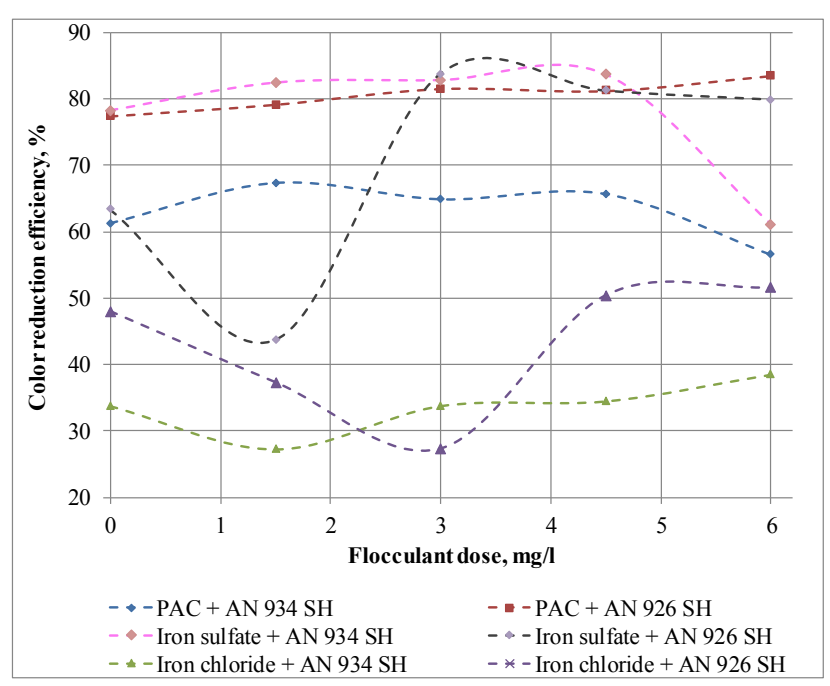

Fig. 7. Color reduction efficiency when using the binary coagulant - anionic flocculant system

For the binary system of iron chloride and AN 934 flocculant, in the range of flocculant doses from 0 to $6 \mathrm{mg} / \mathrm{l}$, the color reduction efficiency was $30.0 \div 38.5 \%$. When adding AN 926 flocculant with a lower charge density at low doses $(1.5 \div 3 \mathrm{mg} / \mathrm{l})$, a decrease in the color reduction efficiency to $37.3 \%$ and $27.3 \%$, respectively, is observed. The subsequent increase in the flocculant dose to $4.5 \mathrm{mg} / \mathrm{l}$ increases the efficiency to $50.4 \%$. The subsequent increase in the flocculant dose does not significantly increase the treatment efficiency (Fig. 6).

For the polyaluminum chloride coagulant, the introduction of AN $926 \mathrm{SH}$ and AN $934 \mathrm{SH}$ anionic flocculants hardly affects the color reduction efficiency.

\section{Discussion of the results of the study of the effect of $\mathrm{pH}$ of the medium and reagent dose on the process of wastewater coagulation}

The results of studies on the determination of rational doses of coagulants and $\mathrm{pH}$ of wastewater are given in Table 2 .

Table 2

Optimum $\mathrm{pH}$ values of wastewater and coagulant doses

\begin{tabular}{|c|c|c|}
\hline Coagulant & Optimum $\mathrm{pH}$ & Coagulant dose $\mathrm{mg} / \mathrm{l}$ \\
\hline Iron sulfate & $5.1 \div 5.7$ & 110 \\
\hline Iron chloride & $6.2 \div 6.7$ & 80 \\
\hline Polyaluminum chloride & $5.9 \div 6.4$ & 140 \\
\hline
\end{tabular}

As can be seen from this table, the maximum values of treatment rate for all investigated coagulants are achieved in weakly acid solutions with $\mathrm{pH}$ in the range of $5.1 \div 6.7$. The lowest $\mathrm{pH}$ is characteristic of sulfate, and the highest iron chloride. At the specified $\mathrm{pH}$ values, along with the formation of the hydroxide of the corresponding metals, hydrocomplexes with a high degree of polymerization and polycations, which are capable of being adsorbed on the surface of negatively charged colloids can be formed [16]. This fact allows achieving a high removal efficiency of suspended solids.
The coagulation threshold for the studied coagulants is the dose in the range from 80 to $140 \mathrm{mg} / \mathrm{l}$. When the coagulant dose is reduced, the efficiency of treatment decreases and its increase does not lead to a noticeable improvement in the treatment quality, while the consumption of reagents increases.

An interesting fact is the presence of a correlation between the rational $\mathrm{pH}$ and the coagulant dose. So, if the application of iron chloride, as already noted, requires a higher $\mathrm{pH}$ than for other coagulants, then the rational dose of this substance is the smallest. At the same time, the minimum $\mathrm{pH}$ characteristic of iron sulfate is combined with its maximum dose.

On the basis of the data obtained, it can be said that the use of iron-containing coagulants is more effective for treatment of wastewater of turkey meat processing enterprises. The removal efficiency of suspended solids, both with the use of aluminum-containing and iron-containing coagulants, is comparable. However, when using polyaluminum chloride, the color of the treated sample remains from pale pink to burgundy, which indicates an insufficient depth of the coagulation process.

Among iron-containing coagulants, iron sulfate is more effective because it has a high efficiency of suspended solids removal and color reduction. Its considerable advantage, in comparison with iron chloride, is that it remains highly efficient in a wider range of $\mathrm{pH}$ values of the medium. This is a significant advantage in the conditions of industrial wastewater, the composition of which can change drastically.

The quality of treatment when using cationic and anionic flocculants is almost the same, however, a rational dose of the cationic flocculant is somewhat lower. The suspended solids removal efficiency when adding the flocculant after wastewater coagulation is increased, on average, by $5 \div 7 \%$. There is also a significant increase in the size of flakes, which leads to a faster settling of the coagulated agglomerates, decrease in the volume of sediment and reduction in its moisture content. The rational dose of the cationic flocculant is $1.5 \mathrm{mg} / \mathrm{l}$.

The results of the study can be used in the design of local treatment facilities of food industry enterprises, where the composition of wastewater is close to that studied in this work. An important area of further research is the identification of the factors that significantly affect the process conditions of physicochemical treatment of waste liquids and quantitative assessment of this effect.

\section{Conclusions}

1. Rational $\mathrm{pH}$ ranges of the medium for coagulation are: $5.1 \div 5.7$ for iron sulfate; $6.2 \div 6.7$ - for iron chloride; $5.9 \div 6.4$ - polyaluminum chloride.

2. The coagulation threshold is the coagulant dose: $110 \mathrm{mg} / \mathrm{l}$ for iron sulfate; $80 \mathrm{mg} / \mathrm{l} \mathrm{-} \mathrm{for} \mathrm{iron} \mathrm{chloride;}$ $140 \mathrm{mg} / 1$ - polyaluminum chloride.

3. Cationic flocculants, the application of which increases the efficiency of suspended solids removal by $5 \div 7 \%$ and color reduction by $10 \div 13 \%$ are the most preferable.

4 . The best result of wastewater treatment was achieved when using the binary system of coagulant - iron sulfate at a dose of $110 \mathrm{mg} / \mathrm{l}, \mathrm{pH}$ of the medium of $5.1 \div 5.6$ and anionic flocculant at a dose of $1.5 \mathrm{mg} / \mathrm{l}$. The efficiency of suspended solids removal achieved in the laboratory was $99.4 \%$ and color reduction $-84.2 \%$. 


\section{References}

1. Promyslovist Ukrainy u 2011-2015 rokakh: statyst. zb. / Derzhavna sluzhba statystyky Ukrainy. Kyiv: B.v., 2016. 381 p.

2. Water consumption and wastewater generation and treatment in the Food and Beverage Industry / Valta K., Kosanovic T., Malamis D., Moustakas K., Loizidou M. // URL: http://uest.gr/winflife/images/papers/valta_et_al.pdf

3. Shtepa V. M. Obgruntuvannia alhorytmu eksperymentalno-analitychnykh rezhymiv elektrotekhnichnoi ochystky stichnykh vod ahropromyslovykh ob'iektiv z metoiu pobudovy enerhoefektyvnykh system upravlinnia // Enerhetyka i avtomatyka. 2014. Issue 2. P. 61-71.

4. Mekonnen M. M., Hoekstra A. Y. A Global Assessment of the Water Footprint of Farm Animal Products // Ecosystems. 2012. Vol. 15, Issue 3. P. 401-415. doi: 10.1007/s10021-011-9517-8

5. Gerbens-Leenes P. W., Mekonnen M. M., Hoekstra A. Y. The water footprint of poultry, pork and beef: A comparative study in different countries and production systems // Water Resources and Industry. 2013. Vol. 1-2. P. 25-36. doi: 10.1016/j.wri.2013.03.001

6. Modernizaciya tekhnologii ochistki zhirosoderzhashchih stochnyh vod i obrazuyushchegosya osadka predpriyatiya po pererabotke myasa ptic / Menshutin Yu. A., Potanina V. A., Kerin A. S., Bogateev I. A., Fomicheva E. V., Sahno A. P., Kerin K. A. // Materialy 11-go Mezhdunarodnogo kongressa «Voda: ekologiya i tekhnologiya» EKVATEK-2011. Moscow: ZAO «Firma SIBIKO Internesh$\mathrm{nl}, 2011.1$ el. opt. disk (CD- ROM).

7. Nacheva P. M., Pantoja M. R., Serrano E. A. L. Treatment of slaughterhouse wastewater in upflow anaerobic sludge blanket reactor // Water Science \& Technology. 2011. Vol. 63, Issue 5. P. 878 doi: 10.2166/wst.2011.265

8. Bustillo-Lecompte C. F., Mehrvar M., Quiñones-Bolaños E. Combined anaerobic-aerobic and UV/H2O2processes for the treatment of synthetic slaughterhouse wastewater // Journal of Environmental Science and Health, Part A. 2013. Vol. 48, Issue 9. P. 1122-1135. doi: 10.1080/10934529.2013.774662

9. Sugito, Binawati D. K., Al Kholif M. The effect of BOD remove influent to remove pollutant load in waste waterof chicken slaughterhose // ARPN Journal of Engineering and Applied Sciences. 2016. Vol. 11, Issue 5. P. 3519-3524.

10. Dabhi M. Physicochemical treatment of dairy plant wastewater using ferrous sulfate and ferric chloride coagulants // International Journal of Basic and Applied Chemical Sciences. 2013. Vol. 3, Issue 4. P. 9-14.

11. Decolourization of the reconstituted textile effluent by different process treatments: Enzymatic catalysis, coagulation/flocculation and nanofiltration processes / Khouni I., Marrot B., Moulin P., Ben Amar R. // Desalination. 2011. Vol. 268, Issue 1-3. P. 27-37. doi: 10.1016/j.desal.2010.09.046

12. Effektivnye tekhnologii ochistki stochnyh vod pri uboe skota i pticy / Garzanov A. L., Lisicyn A. B., Gorbunova N. A., Sitnikova O. I., Giro T. M. // Myasnaya industriya. 2016. Issue 11. P. 28-30.

13. Application of chemical coagulation process for direct dye removal from textile wastewater / Dalvand A., Ehrampoush M., Ghaneian M. et. al. // J. Environ Health Sustain Dev. 2017. Vol. 2, Issue 3. P. 333-339.

14. Effect of $\mathrm{pH}$ and time on the treatment by coagulation from slaughterhouse of the city of Rabat / Boughou N., Majdy I., Cherkaoui E., Khamar M., Nounah A. // MATEC Web of Conferences. 2018. Vol. 149. P. 02091. doi: 10.1051/matecconf/201714902091

15. Study of the coagulation process in wastewater treatment of dairy industries / Loloei M., Nekonam G., Alidadi H., Kor Y. // International Journal of Environmental Health Engineering. 2014. Vol. 3, Issue 1. P. 12. doi: 10.4103/2277-9183.132684

16. Manh B., Thi G. D. Coagulation in treatment of swine slaughterhouse wastewater // DE Gruyter. 2017. Issue 1. P. $15-21$.

17. Spiridonova L. G. Otrabotka rezhimov ochistki stochnyh vod pticefabriki po pererabotke myasa indeek // Vestnik SGASU. Gradostroitel'stvo i arhitektura. 2013. Issue 4. P. 70-74.

18. Coagulation/adsorption combined treatment of slaughterhouse wastewater / Mahtab A., Tariq M., Shafiq T., Nasir A. // Desalination and Water Treatment. 2009. Vol. 12, Issue 1-3. P. 270-275. doi: 10.5004/dwt.2009.952 